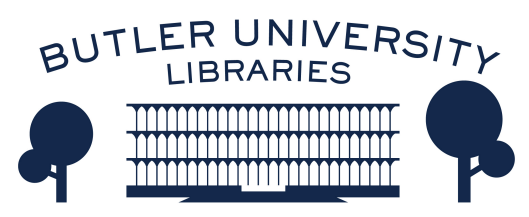

Journal of Hindu-Christian Studies

Volume 25

Article 16

November 2012

\title{
Book Review: "Ramanuja and Schleiermacher: Toward a Constructive Comparative Theology," Jon Paul Sydnor
}

Sucharita Adluri

Follow this and additional works at: https://digitalcommons.butler.edu/jhcs

Part of the Religion Commons

\section{Recommended Citation}

Adluri, Sucharita (2012) "Book Review: "Ramanuja and Schleiermacher: Toward a Constructive Comparative Theology," Jon Paul Sydnor," Journal of Hindu-Christian Studies: Vol. 25, Article 16.

Available at: https://doi.org/10.7825/2164-6279.1522

The Journal of Hindu-Christian Studies is a publication of the Society for Hindu-Christian Studies. The digital version is made available by Digital Commons @ Butler University. For questions about the Journal or the Society, please contact cbauman@butler.edu. For more information about Digital Commons @ Butler University, please contact digitalscholarship@butler.edu. 


\section{Ramanuja and Schleiermacher: Toward a Constructive Comparative Theology. Jon Paul Sydnor. Princeton Theological Monograph Series. Pickwick Publications, 2011,}

\section{6 pages.}

IN this comparative study Sydnor explores the doctrine of absolute dependence on Narayana/God as conceived by Ramanuja (1017-1137) and Schleiermacher (1768-1834), theologians in the Hindu Srivaisnava and the Reformed Christian traditions respectively. Utilizing the Vedarthasamgraha, Brahmasutrabhasya, and Bhagavadgitabhasya of the former and Der christliche Glaube of the latter, he succeeds in bringing into conversation two seminal thinkers from different traditions. Sydnor does not simply read the theological texts pointing out similarities and differences, but in addition to this critical comparison, he also tries to understand each theology in light of the other. In this, he is even-handed, and his documentation and analysis of the relevant texts is one of the greatest strengths of this book.

Chapters one and two lay the groundwork for the rest of the volume. While the first chapter examinines the texts and the intellectual milieu in which both theologians lived and wrote, the second chapter defines the concepts and terms central to the doctrine of absolute dependence according to Ramanuja and Schleiermacher. It also details the methodology of comparative constructive theology, and this section would have been better situated in the first chapter so the reader need not wait until page thirty. An important aspect that these two chapters underscore is the characteristic ontological perspective of Ramanuja and the phenomenological outlook of Schleiermacher. Given this diverse outlook, Sydnor's task of comparative theological investigation seems at first, to be daunting, but his topic of the doctrine of absolute dependence allows him to artfully navigate that incongruence.

Chapter three on the nature of Narayana/God draws attention to the vastly different ways in which both theologians envision the divine. While Ramanuja is prone to anthropomorphizing Narayana, Schleiermacher resists this tendency to objectify God, which is consonant with his view that God is first of all a feeling (gefühl), a kind of awareness. Moreover, divine essence is found united with human nature in the embodiment of Christ. Ramanuja posits two forms of Narayana, an abstract, proper form (svarupa) and a concrete, divine form (divyarupa). The proper form (svarupa) is described as comprised of auspicious qualities such as infinite knowledge, bliss, purity, and so on. The concrete form (divyarupa) has a human-like form, beautiful to behold, possessing four to eight arms and is similar to some of the iconic forms of Narayana in Hindu temples. Ramanuja's followers have explained the divine form as a manifestation of the proper form. In comparing the two theologies, Sydnor makes an interesting suggestion that "[w]hereas Narayana possesses divine transcendence and personality in one person, Schleiermacher offers a more abstract God concretized by the divine-communicating personal existence of Christ". (133) However, conjecturing the divine form (divyarupa) as a more 'concrete' form akin to the figure of Christ is problematic, because even though the divine form (divyarupa) may share some anthropomorphic features, it is still the transcendent form of Narayana, as he exists in Vaikuntha (heaven), composed not of matter, but a pure substance (śuddhasattva). In a way, Sydnor's conclusions regarding the two forms of Narayana are due to the particular translation of the Vedarthasamgraha that he references. The rendering of certain terms in that edition, such as svarupa as 'proper form' and svarupanirupakadharma simply as 'defining attribute', leads Sydnor to posit the comparison between svarupa/divyarupa and God/Christ. The terms in question, are more precisely 
translated as 'essential nature/condition' and as an 'attribute that defines [Brahman's] essential nature', which might not have led the author to the conclusion that he does reach. This underscores the caution with which translated primary sources need to be utilized.

chapters four and five discuss matter and the individual soul, which are dependent on Narayana/God. The comparison of the doctrine of liberation/salvation in chapter five addresses the topic of the state of the soul upon liberation. For Ramanuja, at the time of liberation, the individual self having detached from matter completely, gains back its essential nature, which was partially obscured by its contact with matter. Schleiermacher views redemption as a feeling (gefühl) of absolute dependence mediated through one's sensory self-consciousness. That is, salvation does not mean that the individual soul is completely separated from matter as in Ramanuja's case. Based on this distinction, Sydnor makes an intriguing speculation that the state of liberation in the Srivaisnava sense is "an amorphous collective consciousness", not individual enough, as all contact with matter through which one experiences is lost. However, according to Ramanuja, though the essential individuality of the soul upon liberation is of the nature of consciousness and this is common to all liberated souls, there is an essential individuality to the liberated souls, that he calls indescribable (agocara), and as something known to the selves themselves (svasamvedya). That is, Ramanuja does not eschew individuality between liberated selves,as the plurality of souls is accepted by him. A more in depth analysis of the differences in the definitions of consciousness, mind, sensory awareness, and feeling in the two traditions, would have added more depth to this discussion.

A very helpful conclusion clarifies the advantages and limitations of the constructive comparative methodology and offers a summary of the findings from previous chapters. Altogether, Sydnor's study is a stimulating work and a worthy addition to the growing field of comparative theology. His arguments are convincingly made and the study provides a number of insights into the nature of absolute dependence in the theologies of Ramanuja and Schleiermacher. This study will be of lasting value for scholars of both the Hindu and Christian traditions.

Sucharita Adluri

Cleveland State University

\section{Piety and Responsibility: Patterns of Unity in Karl Rahner, Karl Barth and Vedanta Desika. John N. Sheveland, Farnham, Surrey, England: Ashgate Publishing, 2011, 217 pages.}

RARELY are book titles so descriptive of the actual content of a work. In this volume, John Sheveland, Associate Professor of Religious Studies at Gonzaga University, takes up the theme of the twofold love of God ("piety") and love of neighbor ("responsibility") in the work of the modern Christian theologians Karl Rahner and Karl Barth and the late medieval Srivaisnava teacher Vedanta Desika. Sheveland's argument operates on two levels simultaneously. With regard to the three figures of his study, he employs "piety" and "responsibility" as "vague categories" in the style of Robert Neville to demonstrate a strong thread of unity-or, better, unity-indifference-on the mutual relation of these two loves. "The major thesis," he writes, "asserts an organic unity between the response of piety to God's revelation and the response's attending responsibility to body forth a life in the world transparent to its ground. It is not possible to have either piety or responsibility without the other" (3-4). At a second level of interpretation, precisely because each of his three subjects articulates this organic unity in ways specific to their theological and religious traditions, Sheveland argues that they are most fruitfully set into mutual relation according to 